Dobos Imre':

\title{
Szennyezési jogok hatása a vállalati termelési stratégiára Effect of pollution rights on production strategy of firm
}

A cikk a szennyezési jogok bevezetését vizsgálja a mikroökonómia standard vállalatára. A komparatív statika módszerével vizsgáljuk a termelő vállalat lehetséges reakcióit a szennyezési jog bevezetésére. A vállalatok stratégiája a szennyezési jog bevezetésére a technológia változatlanul hagyása, vagy megváltoztatása lehet. Az egyes esetekben arra keresünk választ, hogy hogyan változik a vállalat nyeresége a bevezetés előtti állapothoz képest, és ez milyen szennyezési stratégiával jár. Szennyezési jogot elad-e, vagy vesz a vállalat a szennyezési jogok piacán?

The paper deals with the effect of an introduction of tradable permits on the production strategy of a firm. It is assumed that the firm will maximize its profit. After introducing the emission trading the profit function will contain the linear emission procurement/selling costs. We will compare the optimal production strategy before tradable permits and after that. The mathematical investigation is based on the nonlinear mathematical programming.

\section{Bevezetés}

A tanulmány a szennyezési jogok bevezetését vizsgálja a mikroökonómia nyereségmaximalizáló vállalatára. A szennyezési jog egy olyan környezetvédelmi szabályozási eszköz, ami a határérték megoldás és a környezetvédelmi adók müködési mechanizmusát egyesíti. E szabályozási eszköz részletes leírását Cropper és Oates [1992] cikke tartalmazza, de környezetgazdaságtani tankönyvek is külön fejezetet szentelnek e témának (lásd [Field, 1997].)

A piacosítható szennyezési jog az externáliák, például szén-dioxid vagy kén -dioxid kibocsátás káros hatásait próbálja internalizálni, azaz ezen környezeti jószágokat teszi piaci jószággá [Varian, 1991]. Arrow megmutatta, hogy a jószágok körének kibővítésével a környezeti javak is az árrendszer befolyása alá vonhatóak egy általános egyensúlyelméleti vizsgálatban [Montgomery, 1972]. Ezt úgy interpretálhatjuk, hogy a környezeti jószágok a vállalatok termelési függvényébe beépíthetők, azok termelési tényezőnek tekinthetők [Cropper és Oates, 1992; Dinkelbach és Rosenberg, 2002; Feldmann, 2002]. Ugyanakkor a környezetszennyezés (emisszió) a vállalatok melléktermékeként jelenik meg, tehát ikerterméke a termelésnek [Dinkelbach és Rosenberg, 2002].

A szennyezési jogok gazdasági vizsgálatánál a jogok piacának müködése, a jogok kereskedelme kerül az érdeklődés homlokterébe [Kling-Rubin, 1997; Majláth, 2002]. Kevés szó esik arról, hogy a vállalatok hogyan reagálnak a szennyezési jogok bevezetésére. A szerzők, ha érintik is a vállalati reakciókat, azt csak egy első lépcsőnek tekintik a piac müködésének leírásához [Montgomery, 1972; Kling-Rubin, 1997; Cronshaw-Kruse, 1996; Kogan-Chernonog, 2019].

\footnotetext{
${ }^{1}$ egyetemi tanár, Budapesti Müszaki és Gazdaságtudományi Egyetem, Gazdaság- és Társadalomtudományi Kar, Közgazdaságtan Tanszék 
A vállalati reakciókat először Dinkelbach és Rosenberg [2002] vizsgálta egy Cobb-Douglas típusú termelési függvény és egyetlen jog esetén. Elöállították a vállalat nyereségfüggvényét azon feltételezés mellett, hogy a vállalat nem osztható szennyezési jogot szerezhet csak be. A megvásárolt, de a vállalat által fel nem használt jogot úgy interpretálták, mint amivel a környezet „egészségesebbé” válik a csökkenő emisszió miatt. Feldmann [2002] a Koopmans-féle lineáris tevékenységelemzési modellben a jogok csomagját vizsgálja, és megállapítja, hogy a technológiák és jogi csomagok között nem létesíthető mindig helyettesíthetőség. Majláth [2002] egy egyszerü mikroökonómiai modellben azt mutatja meg, hogy a szennyezési jogok bizonyos esetekben kontraszelekcióhoz vezethetnek, amikor éppen a környezetkímélő vállalatok csökkentik a termelésüket.

Ettől a szabályozási (piaci) eszköztől azt várják, hogy a bevezetése a vállalatokat technológiaváltásra készteti, azaz olyan új technológiát alkalmaznak a vállalatok, amely hatékonyabb és a környezetet is kevésbé terheli. Kocsis [1998] és Milliman et al. [1989] részletesen vizsgálják a technológiaváltás következményeit a mikroökonómia eszköztárának segítségével. A cikk ezt a várt hatásmechanizmust teszteli egy mikroökonómiai modellben.

Két alapesetet vizsgálunk: a vállalat nem vált technológiát és technológiát vált a szennyezési jogok bevezetése után. Először azt kérdezzük, hogy mi történik akkor, ha a szennyezési jog bevezetése után a vállalat nem változtat a technológiáján; hogyan alakul ekkor a vállalat termelési stratégiája. A második kérdés azt az esetet vizsgálja, amikor a szennyezési joggal együtt technológiát is vált a vállalat, ami három lehetséges módon mehet végbe. Csak a termelési technológiát teszi hatékonyabbá, míg a szennyezőanyagok kibocsátása változatlan marad, vagy a technológia változatlan, de az emisszió csökken, és végül a termelési technológia hatékonyabbá válik, és ezzel egyidőben a szennyezés is alacsonyabbá válik. Az a kérdés merül fel a technológiaváltással kapcsolatban, hogy ezen megoldások közül melyik esetén lesz a nyereség a legmagasabb. Ezután azt kérdezzük, hogy a legnyereségesebb technológia bevezetése esetén vásárolni vagy eladni kell-e szennyezési jogot. A három kérdésre komparatív statikai vizsgálattal keresünk választ. Ezzel eldönthetővé válik az a kérdés, hogy a szennyezési jogok bevezetése valóban környezettudatos technológiák bevezetésére sarkallja-e a vállalatokat.

\section{A vizsgált modellek}

A klasszikus mikroökonómia vállalatát vizsgálva azzal a feltételezéssel élünk, hogy a vállalat árelfogadó, tehát az árak alakulására semmilyen hatással nincs, vagyis exogén árakkal szembesül. Az elérhető termelési technológiákat ismertnek tételezzük fel a szennyezési jog bevezetése előtt és után is. Ezen mellékfeltétel mellett maximalizálja a vállalat a nyereségét. A modell paraméterei és jelölései:

- y a kibocsátás, nemnegatív,

- $\alpha$ a szennyezőanyag kibocsátás, nemnegatív,

- $\Delta \alpha$ a vásárolt vagy eladott szennyezési jog, negatív eladás és nempozitív vásárlás esetén,

- $\underline{x} \quad$ a termeléshez felhasznált inputok vektora, nemnegatív,

- $f_{b}(\underline{x})$ az $\underline{x}$ inputhoz tartozó maximális kibocsátás a szennyezési jog bevezetése előtt, kétszer folytonosan differenciálható, $\underline{x}$-ben nemnegatív, monoton növekvő és szigorúan konkáv, (termelési függvény),

- $g_{b}(y)$ a kibocsátástól függő szennyezőanyag emisszió a szennyezési jog bevezetése előtt, kétszer folytonosan differenciálható, $y$-ban nemnegatív, monoton növekvő és szigorúan konvex, $\alpha=g(y)$,

- $f_{a}(\underline{x})$ az $\underline{x}$ inputhoz tartozó maximális kibocsátás a szennyezési jog bevezetése után, kétszer folytonosan differenciálható, $\underline{x}$-ben nemnegatív, monoton növekvő és szigorúan konkáv, (termelési függvény), 
- $g_{a}(y)$ a kibocsátástól függő szennyezőanyag emisszió a szennyezési jog bevezetése után, kétszer folytonosan differenciálható, $x$-ban nemnegatív, monoton növekvő és szigorúan konvex, $\alpha=g_{a}(y)$,

- $p \quad$ egységnyi végtermék eladási ára, pozitív,

- $q$ egységnyi input beszerzési ára, pozitív,

- $d \quad$ egységnyi szennyezési jog piaci ára, pozitív.

A továbbiakban feltesszük, hogy

$$
\begin{aligned}
& f_{b}(\underline{x})<f_{a}(\underline{x}) \\
& g_{b}(y)>g_{a}(y)
\end{aligned}
$$

ami azt jelenti, hogy az új termelési technológiával azonos input esetén többet lehet előállítani, és a bevezetett új környezetvédelmi technológiával a szennyezőanyag emissziója is csökken, azonos mértékü kibocsátás mellett. A modell anyagáramlási folyamatát az 1. ábra mutatja.

1. ábra: Anyagáramlás a modellben

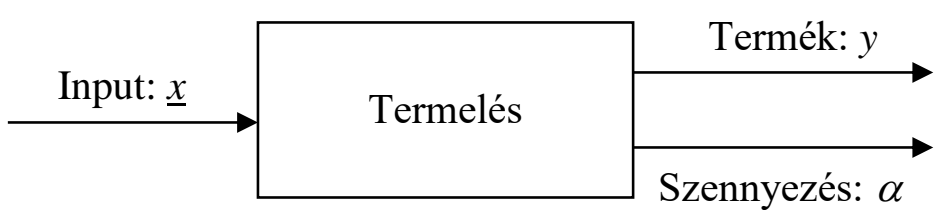

Forrás: saját szerkesztés

$\mathrm{Az}(\mathrm{F})$ alapmodellt a szennyezési jog bevezetése előtt a klasszikus mikroökonómia termeléselméleti optimalizálási modellje képviseli:

$$
\begin{aligned}
& y \geq 0, \underline{x} \geq \underline{0} \\
& y \leq f_{b}(\underline{x}) \\
& p \cdot y-\underline{q} \cdot \underline{x} \rightarrow \max
\end{aligned} .
$$

Tételezzük fel, hogy az optimalizálási problémát megoldottuk, és legyen az optimális megoldás: $\left(y^{b}, \underline{x}^{b}\right)$. A szennyezési jog bevezetésénél az induló állapot - feltevésünk szerint - a bevezetést megelőző termelési szint, amely ekkor a maximális nyereséghez tartozó emisszió. Az ekkor még szabad szennyezés mértéke az optimumban $g_{b}\left(y^{b}\right)=\alpha^{b}$, amit az induló rendelkezésre álló szennyezésnek tekintünk.

A szennyezési jog bevezetése után a vállalatnak két döntési alternatívája van: technológiát vált vagy sem. Ha a vállalat nem változtat sem a termelési, sem az emissziós technológián, akkor a módosított (F1) feladat a következő formában írható fel:

$$
\begin{aligned}
& y \geq 0, \underline{x} \geq \underline{0}, \Delta \alpha \in \mathfrak{R} \\
& y \leq f_{b}(\underline{x}) \\
& g_{b}(y) \leq \alpha^{b}+\Delta \alpha \\
& p \cdot y-\underline{q} \cdot \underline{x}-d \cdot \Delta \alpha \rightarrow \max
\end{aligned}
$$

A harmadik egyenlőtlenség azt fejezi ki, hogy a szennyezőanyagok kibocsátása nem lehet nagyobb, mint a jogok kiosztásánál megállapított mennyiség és annak beszerzett/eladott mennyiséggel növelt/csökkentett értéke. Legyen ennek a feladatnak az optimális megoldása $\left(y^{a_{1}}, \underline{x}^{a_{1}}, \Delta \alpha^{a_{1}}\right)$. 
Térjünk rá azokra az esetekre, amikor a vállalat technológiát vált. A technológiaváltásra három lehetősége van. Az egyik az, ha csak a szennyezőanyag kibocsátását csökkenti az új technológiával, de a termelési technológiáján nem változtat. Ezt az esetet az (F2) probléma szemlélteti:

$$
\begin{aligned}
& y \geq 0, \underline{x} \geq \underline{0}, \Delta \alpha \in \mathfrak{R} \\
& y \leq f_{b}(\underline{x}) \\
& g_{a}(y) \leq \alpha^{b}+\Delta \alpha \\
& p \cdot y-\underline{q} \cdot \underline{x}-d \cdot \Delta \alpha \rightarrow \max
\end{aligned}
$$

Tegyük fel, hogy az optimumot ebben az esetben a $\left(y^{a_{2}}, \underline{x}^{a_{2}}, \Delta \alpha^{a_{2}}\right)$ vektornál éri el a vállalat.

Az következő vizsgálandó modellben a szennyezőanyag kibocsátása változatlan marad, de hatékonyabb termelési technológiát választ a vállalat:

$$
\begin{aligned}
& y \geq 0, \underline{x} \geq \underline{0}, \Delta \alpha \in \mathfrak{R} \\
& y \leq f_{a}(\underline{x}) \\
& g_{b}(y) \leq \alpha^{b}+\Delta \alpha \\
& p \cdot y-\underline{q} \cdot \underline{x}-d \cdot \Delta \alpha \rightarrow \max
\end{aligned}
$$

Erre az esetre az optimális megoldást a $\left(y^{a_{3}}, \underline{x}^{a_{3}}, \Delta \alpha^{a_{3}}\right)$ vektor képviseli.

Az utolsó modellben megváltoztatjuk az emissziós és a termelési technológiát is:

$$
\begin{aligned}
& y \geq 0, \underline{x} \geq \underline{0}, \Delta \alpha \in \mathfrak{R} \\
& y \leq f_{a}(\underline{x}) \\
& g_{a}(y) \leq \alpha^{b}+\Delta \alpha \\
& p \cdot y-\underline{q} \cdot \underline{x}-d \cdot \Delta \alpha \rightarrow \max
\end{aligned}
$$

Ehhez a feladathoz tartozó optimum $\left(y^{a_{4}}, \underline{x}^{a_{4}}, \Delta \alpha^{a_{4}}\right)$.

Technológiaváltás esetén felmerül a kérdés, hogy a három lehetséges fejlesztés közül melyik jár a legnagyobb nyereségnövekedéssel. Mivel ebben a cikkben eltekintünk a technológiaváltással járó fix költségek beruházásra gyakorlott hatásától, ezért csak a legjobb fejlesztés utáni technológia nyereségszintjét vetjük össze a technológiaváltás nélküli esettel.

A feltett kérdések megválaszolásához az (F1), valamint az $(\mathrm{F} 2)-(\mathrm{F} 4)$ problémák optimális megoldását kell összehasonlítanunk az (F) feladat optimális megoldásával ahhoz, hogy válaszolni tudjunk arra a kérdésre, hogy hogyan módosul a termelési stratégia a szennyezési jog bevezetése után. Mielőtt a vizsgálódásainkra rátérnénk, a szennyezési jog bevezetése után adódó problémákat analizáljuk együttes szerkezetben, eltekintve attól, hogy történt-e technológiai változás.

\section{A problémák matematikai struktúrája szennyezési joggal}

Mielőtt az optimális termelési stratégiákat előállítanánk, az (F1)-(F4) problémák matematikai struktúráját vizsgáljuk. Ehhez egy általános feladatcsoportot tekintünk, eltekintve attól, hogy a szennyezési jog bevezetése után éppen a termelési összefüggést vagy a szennyezőanyag kibocsátását teszi hatékonyabbá a vállalat. Vizsgáljuk általánosan a következő problémát: 
$y \geq 0, \underline{x} \geq \underline{0}, \Delta \alpha \in \mathfrak{R}$

$y \leq f_{i}(\underline{x})$

$g_{j}(y) \leq \alpha^{b}+\Delta \alpha$

$(i=b, a ; j=b, a)$.

$p \cdot y-\underline{q} \cdot \underline{x}-d \cdot \Delta \alpha \rightarrow \max$

Először a mellékfeltételeket tekintjük. Azt fogjuk belátni, hogy optimum esetén a termelési összefüggést leíró egyenlőtlenség egy termelési függvénnyé válik, valamint azt, hogy éppen annyi szennyezési jogot vásárol a vállalat, amennyi a maximális nyereség termeléséhez szükséges.

Tételezzük fel, hogy a termelési összefüggés az optimumban szigorúan nagyobbra teljesül, vagyis a termelési halmaz belsejében van az optimum: $y^{o}<f_{i}\left(\underline{x}^{o}\right)$, ahol jelölje $\left(y^{o}, \underline{x}^{o}, \Delta \alpha^{o}\right)$ az általános optimális megoldást. Ha ez így lenne, akkor még lehetne csökkenteni a felhasználást, amivel növelhető lenne a nyereség a költségcsökkentésen keresztül. Ez ellentmond annak a feltevésnek, hogy $\left(y^{o}, \underline{x}^{o}, \Delta \alpha^{o}\right)$ vektor optimális, tehát az összefüggésnek szigorú egyenlőség formájában kell teljesülnie. Hasonló érveléssel bizonyítható, hogy $g_{j}\left(y^{o}\right)=\alpha^{b}+\Delta \alpha^{o}$. Ebben az esetben a szennyezési jog célfüggvényben lévő linearitását kell kihasználnunk. Ezzel beláttuk a következő lemmát.

1. lemma: $\quad \mathrm{A}\left(y^{o}, \underline{x}^{o}, \Delta \alpha^{\rho}\right)$ optimális termelési stratégia a következő probléma megoldásaként adódik:

$$
\begin{aligned}
& y \geq 0, \underline{x} \geq \underline{0}, \Delta \alpha \in \mathfrak{R} \\
& y=f_{i}(\underline{x}) \\
& g_{j}(y)=\alpha^{b}+\Delta \alpha \\
& p \cdot y-\underline{q} \cdot \underline{x}-d \cdot \Delta \alpha \rightarrow \max
\end{aligned} \quad(i=b, a ; j=b, a) .
$$

Megjegyzés. Mivel feltételeztük, hogy a termelési függvény minden nemnegatív $\underline{x}$ vektor esetén szintén nemnegatív, ezért a problémát az

$y=f_{i}(\underline{x})$

$\Delta \alpha=g_{j}(y)-\alpha^{b}$

helyettesítéssel egyszerübb alakra hozhatjuk:

$\underline{x} \geq \underline{0}$

$p \cdot f_{i}(\underline{x})-\underline{q} \cdot \underline{x}-d \cdot g_{j}\left(f_{i}(\underline{x})\right)+d \cdot \alpha^{b} \rightarrow \max \cdot$

Az optimális megoldásokat egyszerü differenciálással meghatározhatjuk, felhasználva a nemnegativitást az $\underline{x}$ vektorra:

$$
p \cdot \frac{d}{d \underline{x}} f_{i}\left(\underline{x}^{o}\right)-\underline{q}-d \cdot \frac{d}{d y} g_{j}\left(f_{i}\left(\underline{x}^{o}\right)\right) \cdot \frac{d}{d \underline{x}} f_{i}\left(\underline{x}^{o}\right) \leq \underline{0},
$$

valamint

$$
\underline{x}^{o} \cdot\left[p \cdot \frac{d}{d \underline{x}} f_{i}\left(\underline{x}^{o}\right)-\underline{q}-d \cdot \frac{d}{d y} g_{j}\left(f_{i}\left(\underline{x}^{o}\right)\right) \cdot \frac{d}{d \underline{x}} f_{i}\left(\underline{x}^{o}\right)\right]=0 \text {. }
$$

Ez a két feltétel nem csak szükséges, hanem elégséges feltétele is az optimumnak, mivel az $f_{i}(\underline{x})$ szigorúan konkáv és $g(y)$ szigorúan konvex függvények. Azonnal látható, hogy a vállalat teljesen leáll a termeléssel, ha

$$
p \cdot \frac{d}{d \underline{x}} f_{i}(\underline{0})-\underline{q}-d \cdot \frac{d}{d y} g_{j}(0) \cdot \frac{d}{d \underline{x}} f_{i}(\underline{0}) \leq \underline{0},
$$

vagyis ekkor a nyereség kizárólag a szennyezési jog teljes eladásából fog származni: $\Delta \alpha^{o}=-\alpha^{b}$. 
Tételezzük most fel, hogy a szennyezési jog bevezetése utáni kiosztásnál induló $\alpha^{b}$ szennyezést kifejezhetjük a szennyezés függvényében, vagyis

$$
\alpha^{b}=g_{j}(\tilde{y}) \quad(j=b, a),
$$

ahol $\tilde{y}=y^{b}$, ha a szennyezési jog bevezetése után nem változtat a vállalat az emisszióján $(j=b)$, míg $\tilde{y}>y^{b}$ ha a vállalat a szennyezési technológiáját környezetbaráttá teszi. Ez utóbbi összefüggés az alábbi egyenlőtlenségből következik:

$$
\alpha^{b}=g_{b}\left(y^{b}\right)=g_{a}(\tilde{y})>g_{a}\left(y^{b}\right),
$$

mivel feltételeztük, hogy az új technológia kevesebb szennyezőanyag kibocsátásával jár.

A továbbiakban nem fogjuk az optimális megoldásokat expliciten kifejezni, hanem ehelyett az optimumok kvalitatív tulajdonságait fogjuk vizsgálni; feltételezve, hogy nem kell a termelést beszüntetni.

\section{Az új technológiák összehasonlítása}

Ebben a részben az (F2)-(F4) feladatok optimális megoldásait fogjuk összevetni annak eldöntéséhez, hogy melyik fejlesztési alternatíva hordozza a legtöbb nyereséget. Az összehasonlítást két lépésben hajtjuk végre. Első lépésben az (F2) és (F4) problémák optimális megoldását tekintjük, majd az (F3) és (F4) problémák nyereségmaximumait hasonlítjuk össze. Az optimális eredmények összevetése az 1. lemmára épül.

Az (F2) probléma optimális megoldása a $\left(y^{a_{2}}, \underline{x}^{a_{2}}, \Delta \alpha^{a_{2}}\right)$ vektor, míg az (F4)-é $\left(y^{a_{4}}, \underline{x}^{a_{4}}, \Delta \alpha^{a_{4}}\right)$. Ekkor a $\left(y^{a_{2}}, \underline{x}^{a_{2}}, \Delta \alpha^{a_{2}}\right)$ vektor egy lehetséges megoldása az (F4) feladatnak, mert

$$
\begin{aligned}
& y^{a_{2}} \geq 0, \underline{x}^{a_{2}} \geq \underline{0}, \Delta \alpha^{a_{2}} \in \mathfrak{R} \\
& y^{a_{2}}=f_{b}\left(\underline{x}^{a_{2}}\right)<f_{a}\left(\underline{x}^{a_{2}}\right) \\
& g_{a}\left(y^{a_{2}}\right)=\alpha^{b}+\Delta \alpha^{a_{2}} .
\end{aligned}
$$

Ez abból következik, hogy az új technológiával azonos inputok mellett több végterméket lehet előállítani. Azonban ez nem optimális, így $p \cdot y^{a_{2}}-\underline{q} \cdot \underline{x}^{a_{2}}-d \cdot \Delta \alpha^{a_{2}}<p \cdot y^{a_{4}}-\underline{q} \cdot \underline{x}^{a_{4}}-d \cdot \Delta \alpha^{a_{4}}$, ami azt jelenti, hogy az (F4) feladat optimális megoldása nagyobb, mint az (F2) problémáé. Legyen most az (F3) probléma optimális megoldása a ( $\left.y^{a_{3}}, \underline{x}^{a_{3}}, \Delta \alpha^{a_{3}}\right)$ vektor, míg az (F4)-é $\left(y^{a_{4}}, \underline{x}^{a_{4}}, \Delta \alpha^{a_{4}}\right)$. Ebben az esetben a $\left(y^{a_{3}}, \underline{x}^{a_{3}}, \Delta \alpha^{a_{3}}\right)$ vektor egy lehetséges megoldása az (F4) feladatnak, mert

$$
\begin{aligned}
& y^{a_{3}} \geq 0, \underline{x}^{a_{3}} \geq \underline{0}, \Delta \alpha^{a_{3}} \in \mathfrak{R} \\
& y^{a_{3}}=f_{a}\left(\underline{x}^{a_{3}}\right) \\
& g_{a}\left(y^{a_{3}}\right)<\alpha^{b}+\Delta \alpha^{a_{3}}=g_{b}\left(y^{a_{3}}\right)
\end{aligned},
$$

de az új technológiával az emisszió csökken. Így ez nem lehet optimális program: $p \cdot y^{a_{3}}-\underline{q} \cdot \underline{x}^{a_{3}}-d \cdot \Delta \alpha^{a_{3}}<p \cdot y^{a_{4}}-\underline{q} \cdot \underline{x}^{a_{4}}-d \cdot \Delta \alpha^{a_{4}}$, ami azt jelenti, hogy az (F4) feladat optimális megoldása nagyobb, mint az (F3) problémáé. Ezzel bizonyítást nyert a

2. lemma: Ha vállalat a szennyezési jog bevezetése után technológiaváltásra szánja el magát, akkor a legtöbb nyereséget azzal éri el, ha mind a termelési, mind az emissziós technológiát lecseréli. 
Ezután az előzetes választás után azt fogjuk megvizsgálni, hogy milyen hatással van a technológia (nem) választás a nyereségre, és ez szennyezési jog beszerzéssel vagy eladással jár-e.

\section{Optimális termelési stratégiák a szennyezési jog bevezetése után}

\subsection{A vállalat nem változtat a technológián a szennyezési jog bevezetése után}

Ebben az esetben az (F) feladat és az (F1) feladat optimális megoldását kell összevetnünk. Tételezzük fel, hogy az (F1) feladat optimális megoldása adott, amit $\left(y^{b}, \underline{x}^{b}\right)$ kibocsátás és ráfordítás jelöl. A szennyezőanyagok emissziója ekkor $\alpha^{b}=g_{b}\left(y^{b}\right)$ mennyiség lesz, amit a következő periódusban a vállalat használhat.

Tegyük fel, hogy a vállalat megoldotta az (F1) problémát, aminek a megoldása $\left(y^{a_{1}}, \underline{x}^{a_{1}}, \Delta \alpha^{a_{1}}\right)$. A megoldásokat két lépésben vetjük össze. Az (F1) feladat felírásából következik, hogy annak egy lehetséges megoldása a $\left(y^{b}, \underline{x}^{b}, 0\right)$ vektor, ami egy olyan tevékenységet jelent, amikor a vállalat maximalizálja a nyereségét és nem vesz részt a szennyezési jogok adás-vételében, ugyanis

$y^{b}=f_{b}\left(\underline{x}^{b}\right)$

$g_{b}\left(y^{b}\right)=\alpha^{b}+0$

Ez azt is jelenti, hogy a $\left(y^{b}, \underline{x}^{b}, 0\right)$ vektor nem lehet optimális megoldása az (F1) feladatnak, így $p \cdot y^{b}-\underline{q} \cdot \underline{x}^{b}-d \cdot 0<p \cdot y^{a_{1}}-\underline{q} \cdot \underline{x}^{a_{1}}-d \cdot \Delta \alpha^{a_{1}}$.

Ugyanakkor az $\left(y^{a_{1}}, \underline{x}^{a_{1}}\right)$ vektor egy lehetséges, de nem optimális megoldása az (F) feladatnak, mivel $y^{a_{1}}=f_{b}\left(\underline{x}^{a_{1}}\right)$.

Ezzel azt láttuk be, hogy

$p \cdot y^{a_{1}}-\underline{q} \cdot \underline{x}^{a_{1}}<p \cdot y^{b}-\underline{q} \cdot \underline{x}^{b}$.

A két egyenlőtlenséget összevetve kapjuk a következő egyenlőtlenségeket:

$p \cdot y^{a_{1}}-\underline{q} \cdot \underline{x}^{a_{1}}<p \cdot y^{b}-\underline{q} \cdot \underline{x}^{b}<p \cdot y^{a_{1}}-\underline{q} \cdot \underline{x}^{a_{1}}-d \cdot \Delta \alpha^{a_{1}}$.

Rendezve az egyenlőtlenségeket azt kapjuk, hogy $\Delta \alpha^{a_{1}}<0$, ami azt jelenti, hogy a szennyezési jog kiosztásakor rendelkezésre álló $\alpha^{b}$ szennyezési mennyiségből elad a vállalat. Eredményünket a következő lemma foglalja össze.

3. lemma: Ha a vállalat nem változtat technológiáján a szennyezési jog bevezetése után, akkor a nyeresége nő, mégpedig oly módon, hogy csökken az alaptevékenységéből származó nyereség, amit a szennyezési jog eladásából származó bevétellel kompenzál.

A lemmából az is következik, hogy a vállalat csökkenti a végtermék kibocsátását is, mert $g_{b}\left(y^{a_{1}}\right)=\alpha^{b}+\Delta \alpha^{a_{1}}<g_{b}\left(y^{b}\right)$, ahonnan a $g_{b}(y)$ függvényre tett monotonitási tulajdonság miatt teljesül az állítás, vagyis $y^{a_{1}}<y^{b}$.

Figyeljük meg, hogy a bizonyításhoz nem kellett kihasználnunk az $f_{b}(\underline{x})$ és $g_{b}(y)$ függvények differenciálhatóságát, csak szigorú konkavitását.

\subsection{A vállalat a leghatékonyabb technológiát vezeti be}

Ekkor az (F) és az (F4) feladat optimális megoldását kell összevetnünk. Az előbbi esettel szemben ekkor azzal módosul a probléma, hogy a termelési és emissziós technológia is hatékonyabb. 
Tegyük fel, hogy az (F4) probléma $\left(y^{a_{4}}, \underline{x}^{a_{4}}, \Delta \alpha^{a_{4}}\right)$ megoldása ismert. Az (F4) feladat felírásából következik, hogy annak egy lehetséges megoldása a $\left(y^{b}, \underline{x}^{b}, 0\right)$ vektor, ugyanis

$f_{b}\left(\underline{x}^{b}\right)=y^{b}<f_{a}\left(\underline{x}^{b}\right)$

$g_{a}\left(y^{b}\right)<\alpha^{b}+0=g_{b}\left(y^{b}\right)$

Ez itt is jelenti, hogy a $\left(y^{b}, \underline{x}^{b}, 0\right)$ vektor nem lehet optimális megoldása az (F4) feladatnak, így $p \cdot y^{b}-\underline{q} \cdot \underline{x}^{b}-d \cdot 0<p \cdot y^{a_{4}}-\underline{q} \cdot \underline{x}^{a_{4}}-d \cdot \Delta \alpha^{a_{4}}$.

Ez azt jelenti, hogy az új, környezetkímélő technológia bevezetésével növekedni fog a vállalat nyeresége.

A továbbiakban arra a kérdésre keresünk választ, hogy ez a növekedés miből származik: az alaptevékenységből származó nyereség növekedéséből, vagy abból, hogy a szennyezési jog értékesítéséből tesz szert többletbevételre a vállalat, amint az a technológiaváltás elhanyagolásakor bekövetkezik.

A kérdés megválaszolásához az 1. lemma eredményeit használjuk fel. Vezessük be az (F4) probléma költségfüggvényét, amelyet az alábbi módon definiálhatunk:

$C(y)=\min \left\{\underline{q} \cdot \underline{x} \mid y=f_{a}(\underline{x}), \underline{x} \geq \underline{0}\right\}$.

Ez a függvény monoton növekvő, differenciálható és konvex függvény. [Mas-Collel et al., 1995]. Ennek ismeretében az (F4) feladat $\Pi(y)$ célfüggvényét (nyereségfüggvény) a következő formában írhatjuk fel:

$\Pi_{a}(y)=p \cdot y-C_{a}(y)+d \cdot\left[g_{a}(\tilde{y})-g_{a}(y)\right]$,

ahol $g_{a}(\tilde{y})=\alpha^{b}$ a kiosztott induló szennyezési jogot jelenti, de az új technológia kibocsátásának függvényében. Ez azt jelenti, hogy ha a vállalat éppen $\tilde{y}$ nagyságot termel, akkor nem kell sem eladnia, sem beszereznie szennyezési jogot. A $\Pi_{a}(y)$ függvénynek, amely szigorúan konkáv a feltevések szerint, a maximuma az $y^{a_{4}}$ pontban fekszik. Differenciáljuk ezt a nyereségfüggvényt a kibocsátás szerint $\Pi_{a}^{\prime}(y)=p-C_{a}^{\prime}(y)-d \cdot g_{a}^{\prime}(y)$.

A vállalatnak az össznyereség maximalizálásához akkor kell szennyezési jogot beszereznie, ha ez a nyereségfüggvény a $\tilde{y}$ pontban pozitív, vagyis itt a profitfüggvény monoton növekvő, míg eladás akkor történik, ha itt negatív a függvény, vagyis a teljes nyereségfüggvény monoton csökkenő e pontban. Ha a függvény deriváltja nulla e pontban, vagyis az induló kiosztás nyereségmaximumot tesz lehetővé, akkor a vállalat nem vesz részt a szennyezési jogok kereskedelmében, mert az induló szennyezési jog éppen fedi az emisszió mértékét.

Ha a vállalatnak nem kell eladnia szennyezési jogot, azaz vásárolnia kell, akkor az alaptevékenységből származó nyeresége is nő, hiszen

$p \cdot y^{b}-\underline{q} \cdot \underline{x}^{b}-d \cdot 0<p \cdot y^{a_{4}}-\underline{q} \cdot \underline{x}^{a_{4}}-d \cdot \Delta \alpha^{a_{4}} \leq p \cdot y^{a_{4}}-\underline{q} \cdot \underline{x}^{a_{4}}$.

Ha a vállalat szennyezési jogot kell eladjon a nyeresége maximalizálásához, akkor az alaptevékenységéből származó nyeresége lehet nagyobb és kisebb is, mint a szennyezési jog bevezetése előtt. Vizsgáljuk azt az esetet, hogy az eladás után mikor növekszik az alaptevékenységből származó nyereség. Ehhez tekintsük a következő módosított feladatot:

$$
\begin{aligned}
& y \geq 0, \underline{x} \geq \underline{0} \\
& y \leq f_{a}(\underline{x}) \\
& g_{a}(y) \leq \alpha^{b}+\Delta \alpha^{a_{4}} . \\
& p \cdot y-\underline{q} \cdot \underline{x} \rightarrow \max
\end{aligned}
$$


Ennek a feladatnak az optimális megoldása $\left(y^{a_{4}}, \underline{x}^{a_{4}}\right)$, hiszen az optimális szennyezési jog eladást/vásárlást szerepeltetjük a szennyezés korlátozásánál. Most arra a kérdésre akarunk választ kapni, hogy a szennyezési jog bevezetése előtti termelési stratégia $\left(y^{b}, \underline{x}^{b}\right)$ lehetséges megoldása-e ennek a problémának. Ha egy lehetséges megoldás, akkor $p \cdot y^{b}-\underline{q} \cdot \underline{x}^{b} \leq p \cdot y^{a_{4}}-\underline{q} \cdot \underline{x}^{a_{4}}$, ami azt jelenti, hogy a szennyezési jog bevezetése után növekszik az alaptevékenységből származó nyeresége a vállalatnak. Ez akkor következik be, ha

$$
\begin{aligned}
& y^{b}<f_{a}(\underline{x}) \\
& g_{a}\left(y^{b}\right) \leq \alpha^{b}+\Delta \alpha^{a_{4}}=g_{a}\left(y^{a_{4}}\right),
\end{aligned}
$$

hiszen a $\left(y^{b}, \underline{x}^{b}\right)$ termelési stratégia lehetséges a feltételezésünk szerint. Ez azt jelenti, hogy $y^{b} \leq y^{a_{4}}$, vagyis a jog bevezetése utáni végtermék kibocsátásának nagyobbnak kell lennie, mint az azt megelőzőnek. Ezzel beláttuk a következő lemmát:

4. lemma: Technológiaváltás után a vállalat teljes nyeresége nő. Ha a termékkibocsátását is növeli a vállalat, akkor az alaptevékenységből származó nyereség is nő, eltekintve attól, hogy a vállalat szennyezési jogot elad vagy vesz.

Megjegyzés. A lemma bizonyításának gondolatmentét követve könnyen belátható, hogy ha nem változtat a technológiáján a vállalat, akkor mindenképpen el kell adnia szennyezési jogot, ugyanis ekkor a teljes profitfüggvény

$\Pi_{b}(y)=p \cdot y-C_{b}(y)+d \cdot\left[g_{b}\left(y^{b}\right)-g_{b}(y)\right]$,

ami az $y^{b}$ pontban negatív, mivel $p-C_{b}^{\prime}\left(y^{b}\right)-d \cdot g_{b}^{\prime}\left(y^{b}\right)=-d \cdot g_{b}^{\prime}\left(y^{b}\right)<0$, amiatt, hogy az $y^{b}$ pontban az alaptevékenységből származó nyereség maximális, így annak differenciálja zérus lesz.

\subsection{Váltson-e technológiát a vállalat a szennyezési jog bevezetése után?}

Vessük végül össze a fenti két termelési stratégiát. Könnyen megmutatható, hogy a technológiaváltás nélküli optimális $\left(y^{a_{1}}, \underline{x}^{a_{1}}, \Delta \alpha^{a_{1}}\right)$ stratégia a leghatékonyabb technológiaváltás utáni problémának egy lehetséges megoldása:

$$
\begin{aligned}
& y^{a_{1}} \geq 0, \underline{x}^{a_{1}} \geq \underline{0}, \Delta \alpha^{a_{1}} \in \mathfrak{R} \\
& f_{b}\left(\underline{x}^{a_{1}}\right)=y^{a_{1}}<f_{a}\left(\underline{x}^{a_{4}}\right) \\
& g_{a}\left(y^{a_{1}}\right)<\alpha^{b}+\Delta \alpha^{a_{1}}=g_{b}\left(y^{a_{1}}\right)
\end{aligned} .
$$

Ez abból következik, hogy az új technológiával azonos inputok mellett több végterméket lehet elöállítani és az emisszió is kisebb. Azonban ez nem optimális, így

$p \cdot y^{a_{1}}-\underline{q} \cdot \underline{x}^{a_{1}}-d \cdot \Delta \alpha^{a_{1}}<p \cdot y^{a_{4}}-\underline{q} \cdot \underline{x}^{a_{4}}-d \cdot \Delta \alpha^{a_{4}}$,

vagyis a vállalat nyeresége akkor lesz legnagyobb, ha azonos input mellett a legnagyobb kibocsátást és azonos output mellett a legkisebb szennyezőanyag kibocsátást mutató termelési technológiát vezeti be. Ezt az eredményt az 5. lemmában foglaljuk össze.

5. lemma: Egy termelő vállalat akkor maximalizálja legjobban a nyereségét a szennyezési jogok bevezetése után, ha olyan technológiát vezet be, amely növeli a végtermék kibocsátást, ugyanakkor a szennyezőanyag kibocsátást a minimálisra csökkenti.

Ezzel vizsgálódásaink végére értünk. 


\section{6. Összegzés}

Ebben a dolgozatban a szennyezési jogok bevezetésének hatását vizsgáltuk egy nyereségét maximalizáló vállalat esetére. A technológiaváltás alatt a vizsgálatban a termelési függvény megváltozását értjük. A komparatív statikai vizsgálatban az néztük, hogy technológiaváltással (a technológia cseréjével) vagy anélkül reagáló vállalatnak hogyan alakul a nyeresége. A technológia megváltoztatására három lehetséges alternatívája van a vállalatnak: a termelési és/vagy emissziós technológiák cseréje.

A vizsgálatok arra az eredményre vezettek, hogy ha a vállalat technológiát vált, akkor a legnagyobb nyereségét akkor éri el, ha új, hatékonyabb termelési és emissziós technológiát vezet be, tehát a két technológia együttes bevezetése vezet a legjobb eredményre. Annak a kérdésnek az eldöntésére, hogy technológiaváltásra sarkallja-e a vállalatot a szennyezési jog bevezetése, igenlő választ adhatunk. A technológiaváltással érhető el a nyereség maximális növekedése. A vállalat az új technológia bevezetése után adhat és vehet is szennyezési jogot, míg ha nem vált technológiát csak a szennyezési jog eladásából származik a többletnyereség.

Ebben a tanulmányban eltekintettünk attól, hogy az új technológiák bevezetése pótlólagos beruházási költséggel jár. Az alkalmazott vizsgálati keretet bővíteni lehet és kell is a megelőzési költségek bevezetésével. Felmerül a kérdés, hogy ezen költségek bevezetése hogyan módosítja az új technológia megválasztását. Ugyanakkor a komparatív statikai vizsgálataink során azzal a feltételezéssel éltünk, hogy az árak nem változnak. Egy következő általánosítás ezt a feltevést oldhatná fel. Végül, figyelembe lehetne venni a szennyezési jogok piacán is jelenlevő tranzakciós költségeket, és azok hatásait. E három kérdés beépítése ebbe a modellbe egy újabb dolgozat témája lehet.

Köszönetnyilvánítás. A szerző köszöni az OTKA K 116472 támogatását.

\section{Felhasznált irodalom:}

Cronshaw, M.B., Kruse, J.B. (1996): Regulated firms in pollution permit markets with banking, Journal of Regularory economics 9, 179-189

Cropper, M.L.-Oates, W.E. (1992): Environmental economics: A survey, Journal of Economic Literature XXX, 675740

Dinkelbach, W., Rosenberg, O. (2002): Erfolgs- und umweltorientierte Produktionstheorie, 4. Aufl., Springer, Berlin

Feldmann, M. (2002): Handelbare Umweltzertifikate in der Linearen Aktivitätsanalyse, Zeitschrift für Betriebswirtschaft 72, 673-693

Field, B.C. (1997): Environmental economics: An introduction, 2. Ed., McGraw-Hill, Inc., New York et al.

Kling, C., Rubin, J. (1997): Bankable permits for the control of environmental pollution, Journal of Public Economics 64, 101-115

Kocsis, T. (1998): Szennyezéselhárítás és technológiai fejlödés a környezetgazdaságtanban - mikroökonómiai elemzés, Közgazdasági Szemle 45, 954-970

Kogan, K., Chernonog, T. (2019): Competition under industry-stock-driven prevailing market price: Environmental consequences and the effect of uncertainty. European Journal of Operational Research, 276(3), 929-946.

Majláth, M. (2002): Bemutató modell a piacosítható szennyezési jogok kereskedelmének költségekre, termelésre és szennyezőanyag-kibocsátásra gyakorolt hatásásról, 20. sz. Mühelytanulmány, Vállatgazdaságtan tanszék, Budapesti Közgazdaságtudományi és Államigazgatási Egyetem

Mas-Collel, A., Whinston, M.D., Green, J.R. (1995): Microeconomic theory, Oxford University Press, New York 
Milliman-Prince (1989): Firm Incentives to Promote Technological Change in Pollution Control, Journal of Environmental Economics and Management 17, 247-265

Montgomery, W.D. (1972): Markets in licenses and efficient pollution control programs, Journal of Economic Theory 5, 395-418

Stavins, R.N. (1995): Transaction costs and tradeable permits, Journal of Environmental Economics and Management $29,133-148$

Varian, H.L. (1991): Mikroökonómia középfokon: Egy modern megközelítés, Közgazdasági és Jogi Könyvkiadó, Budapest 